per cent. For several years the average age of the alcoholic patients has shown a tendency to fall, young jersons of 20-30 being more numerous than formerly. Alcoholism was found to be as frequent among the married as among celibates, but was moro liable to affect the rural than tho urban population. In 1936 , for example, only $15 \cdot 73$ per cent of the alcoholic admissions were manual labourers, as compared with farm labourers who formed $\mathbf{4 7 . 2 5}$ per cent of these admissions. The measures suggested by Dr. Le Gall for the control of alcoholism in Morbihan include suppression of tho privilerges allowed to homedistillers, limitation of the number of public houses, the creation of dispensaries of mental hygiene, special homes for inebriates, especially for relapsing cases, the promotion of sport, and the encouragement of propa. ganda in fuvour of non-fermented apple juice, which has yielded oxcellent results in some countries, especially Switzerland.

\section{Earthquake near the New Hebrides}

Tuғ: United States Coast and Geodetic Survey, in co-operation with Science Service and the Jesuit Seismological Associntion, has determined the epicentre of tho earthquale of August 12 to bo provisionally latitudo $13^{\circ} \mathrm{S}$, longitude $169^{\circ} \mathrm{E}$. The instrumental reports from Manila, Sitka, Weston, St. Isouis, Fordhnm, Pasadena, Honolulu and Philadelphia also suggest that the depth of focus from which the shock originated was of the order of $150 \mathrm{~km}$., thus malsing a deep focus earthquake. The epicentro is to the north of the New Hebrides and north-west of Fiji, being submarine in character. No damage has been reported, either directly duo to the shock or to any abnormal sen waves. The region concerned is particularly liable to earthquales and it is also noticeablo that the frequency of earthquakes having deep focus is greater than normal in the whole of the region extending from Japan to the south of Fiji and including the area in question. A now Milne. Shaw eeismograph and high-precision clock with seconds regulator have recently been sent on loan to Fiji by the British Association Seismological Com. mittee at the suggestion of the Seismological Committee of the Australinn and Now Zealand Association for the Advancement of Science to replace the old Milne instrument there. This new seismograph will be particularly valuable for obtaining data for the study of deep focus earthquakes similar to the one mentioned above.

\section{Mathematical Reviews}

'lue American Mathematical Society has founded a new international mathematical abstracting journal to be known as Mathematical Reviews. The first number is to appear late in 1939 or early in 1940 ; the material to be reviewed begins with the latter half of 1933. It is proposed to review all fields of pure mathematics and also those of applied mathematics and mathematical pliysies which are of pronounced interest to mathematicians. 'The new journal, which will be issued approximately onco a month, will contain several thousand reviews annually and will run to approximately eight hundred largo doublo-colurnn pages. Prof. J. D. Tamarkin and Prof. Otto Neugobauer will bo tho first editors. The Carnegie Corpora. tion has appropriated 60,000 dollars as a reserve for the new journal. The Rockefeller Foundation has mado a gift of 12,000 dollars to cover som 3 of tho initial costs. Brown University is housing the project and aiding in the editorial work. The American Mathematical Society and tho Mathemntical Association of America are each beginning with a subsidy of 1,000 dollars for the first year. Annual subsidics are bcing sought from other organizations, and plans for the permanent financing of the project are being considered. On account of the generous subventions, the subscription price will bo set drastically below nctual cost.

PARTr. with the view of aiding indirectly in the support of this journal, the Rockefeller Foundation has made a handsoms gift to Brown University for an experiment in the dissemination of mathematical publications through the distribution of microfilm. 'This money is to be used to augment tho mathomatical library at that University, a collection which is already internationally known as outstanding. Out of-print journals will be put on film and made avail. able to mathematicians; rare books of general uso will bo filmed; on request from a subscriber to the new journal, any articlo reviewed will bo sent on film or as film-print. This servico will bo extended to all parts of the world at a price not exceeding cost. It should be of greatest value to mathematicians in tho smaller universities and colleges, and should be a fuctor in encouraging young men to continue with their investigations.

\section{Matter and Radiation}

No. 704 of Hermann's "Actualités" seriez is by Prof. Louis do Broglie, editor of the volumes on theoretical physics, and is entitled "Lo Principo de Correspondance et les Interastions entre la Matière et le Rayonnement". It extends to 170 pages (Paris: Hermann et Cie. 50 francs). The first 48 pages give an account of Maxwell's equations and their extension by Lorentz to cover electrons; the electromagnetic theory of dispersion; the theory of quantis; the corros. pondenco principlo introduced by Bohr in 1916 ; and Heisenberg's representation of tha atom by a mstrix of quantities all of which are directly observable. Then the principle of wave mzchanics is introduced according to which the movement of miterial co:puscles is based on a certain equation of raves developed from the Hamiltonian function of classical mechanics. It is then shown that wave mechanics includes the correspondence principle and lead 3 to a theory of the interaction of radiation and matter which, though not strictly logical, may b3 regarded as a first approximation. Later sections deal with the diffusion of light energy by matter, first without change of wave-length, then with such chango as are illustrated by the Compton and the Raman effects. 'ilhe volume concludes with a study of photo-elec- 
tricity in which the light quantum passes completely to matter, that is, the photon is annihilated. As one would expect from the author, wave mechanics is treated with great clearness and thero is no attempt to represent the theory as having resolved all diffi. culties; on the contrary, at each partial success its incomplete nature is commented on and the requirements of a more complete solution are specified.

\section{Egg Storage}

A Descrirriox is given in the Electrical Review of September 15 of the Chelmsford Egg Supply Co. (193.1). This company utilizes a process for the preservation of eggs which, it is claimed, keeps them fresh indefinitely. It is said that, if eggs are frozen below $28^{\circ} \mathrm{F}$. they crack, so that storage by freezing is imprasticable. Storage in gas is better, but it takes time for the gas to percolnte through the shell. The company has, however, overcome this difficulty. Fiery egg has a small air space at the top. 'This increases as the egg ages. By means of a pump tho air is extracted and replaced by carbon dioxido and nitrogen under a pressure of $250 \mathrm{~mm}$., this pressure being maint ained all the time the eggs are in storage. The eggs aro stored in large cylinders each holding 234,000 eggs and are kept at a temperaturo of $30^{\circ} \mathrm{F}$. Ench refrigerating unit is driven by a 6 h.p. motor, and in addition, two extra motors are cmployed, 5 h.p. and $2 \cdot 75$ h.p. respectively, for circulating tho water and ammonia. The gas.tight cylinders in which the eggs aro stored look like large boilers. An additional chamber held at a much lower temperature is used for freezing liquid eggs, that is, those which have been accidently cracked, and aro sold to local bakeries. Tho factory is also a national mark packing station capable of dealing with a million and a half eggs a week. Tho electricity taken per annum from the public supply is nearly 60,000 units. As this load is very nearly constant, and is heaviest during tho summer montlıs, the load factor is excellent and an attractive tariff is available. The seasonal differenco in the price of eggs practically makes up for the cost of storage.

\section{Extensions of Carrier Telephone Systems}

Is the quarterly edition (No. 17) of Nippon Electrical Engincering, published in English by the Institute of Electrical Communication Engineers of Japan, there is an important paper on carrier telephone systems which make use of lighting and power distribution lines. It is written by $\mathbf{N}$. Shinohara, $\mathbf{Y}$. Hirano and M. Yoshioka, and contains many useful experimental and theoretical results. They point out that the economies effected by using existing power and lighting circuits as part of the carrier system make it possible to extend communication to out-of-the-wny districts, as, for example, farming listricts, fishing villages, lighthouses, etc. This will unake possible the rapid cultural development of these places. They consider first of all the use of high-tension distribution lines as part of the carrier frequency transmission circuit. In the past this has been done by two systems; the first is called the metallic circuit system and the second the ground return circuit system. Although the first system oxcels the latter so far as low attenuation and noise are concerned, the second is the system which is moro commonly employed owing to its greater economy and trustworthiness. The authors state that in utilizing the high-tension distribution line it is best to employ the ground return circuit system. Tho most commonly employed types of high-tension systems are the single-phase two-wiro type and the threo-phase three-wiro type. The height of the wires above the ground is not uniform, but, whero the lins is oven, the averago height is about seven metres. By considering a singlo copper wiro $5 \mathrm{~mm}$. in diameter at a height of 7 metres above the ground and at a temperature of $20^{\circ} \mathrm{C}$. and $\Omega$ frequency of $50 \mathrm{kc}$., they compute that the speed of the carrier waves is nearly equal to the speed of light and that the attenuation constant is very small. Thoy concludo by describing a method of designing a circuit by a new telephone system which they state will bo the most suitable for a rural district. They show how much moro economical the new system would be than the one at present in use.

\section{Oceanographical Results from Central America}

In July and August 1938, the President of the United States, the Honorable Franklin D. IRooserelt, undertook un inspection eruise and fishing expedition from San Diego, California, to I'ensazola, Florida, by wny of the Panama Canal, aboard the U.S.S. Houston. Between July 16 and August 9 some 5,888 miles were covered and fourteen different collecting stops wero made, distributed among the possessions of five different nations: Mexico (Lower California and Socorro Island), France (Clipperton Island), Ecuador (tho Galapagos Islands), Costa IRica (Cocos Island), and Colombia (Old Providence Island in the Caribbean). Dr. Waldo L. Schmitt of the United States National Museun accompanied tho expedition as a naturalist. The results are published in a series of papers of which four are before us: "Decapod and Other Crustacea" (with Introduction and Data) (Smithsonian Miscellaneous Collections, 98, No. 6, Pub. 353I) by Waldo I. Schmitt; "Molluscs" (Pub. 3535 ) by Paul Bartsch and Harald Alfred Rehder; "A New Holothurian of the Genus 'Thyone" (Pub. 3537) by Elisabeth Deichmann; and "I'wo New Gobioid Fishes" by Isaac Ginsburg (Pub. 3539), May-June 1939. A number of new species of Mollusca are described, and lists of species given from tho various collecting grounds.

\section{Grass Drying}

A nEPOnT on fodder conservation with special reference to grass drying by F. J. Roberts has been published by the Agricultural Research Council (H.M. Stationery Office. 2s.). This is the third report on the subject, and embodies the results of the most recent experiments carried out with the co-operation of agricultural organizers, colleges and experi. mental farms in Great Britain. A detailed account 